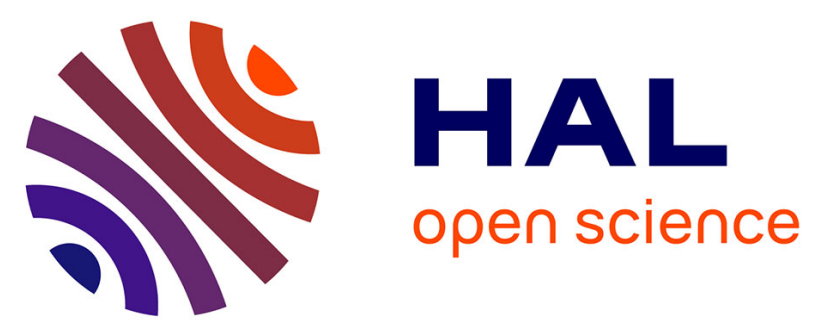

\title{
Study of the formation of acid-based geopolymer networks and their resistance to water by time/temperature treatments
}

Jenny Jouin, Helene Celerier, Lila Ouamara, Nicolas Tessier-doyen, Sylvie Rossignol

\section{To cite this version:}

Jenny Jouin, Helene Celerier, Lila Ouamara, Nicolas Tessier-doyen, Sylvie Rossignol. Study of the formation of acid-based geopolymer networks and their resistance to water by time/temperature treatments. Journal of the American Ceramic Society, 2021, 104 (10), pp.5445-5456. 10.1111/jace.17929 . hal-03402222

\section{HAL Id: hal-03402222 \\ https://hal-unilim.archives-ouvertes.fr/hal-03402222}

Submitted on 26 Nov 2021

HAL is a multi-disciplinary open access archive for the deposit and dissemination of scientific research documents, whether they are published or not. The documents may come from teaching and research institutions in France or abroad, or from public or private research centers.
L'archive ouverte pluridisciplinaire HAL, est destinée au dépôt et à la diffusion de documents scientifiques de niveau recherche, publiés ou non, émanant des établissements d'enseignement et de recherche français ou étrangers, des laboratoires publics ou privés. 


\title{
Study of the formation of acid-based geopolymer networks and their resistance to water by time / temperature treatments
}

Jenny Jouin*, Helene Celerier, Lila Ouamara, Nicolas Tessier-Doyen, Sylvie Rossignol IRCER: Institut de Recherche sur les Céramiques (UMR CNRS 7315), Centre Europeen de la Ceramique, 12 rue Atlantis, 87068 Limoges Cedex, France.

* Corresponding author: jenny.jouin@unilim.fr

\begin{abstract}
Acid-based geopolymers are known for their high temperature resistance and good mechanical performances. Some compositions also exhibit water resistance, which make them suitable for outdoor applications. This work aims to understand accurately the steps occurring during the geopolymerization process, and focuses on the type of networks forming at early stages of the reaction. The sample, prepared from metakaolin and phosphoric acid, has been analyzed at different durations and temperatures during its solidification, in order to identify which compounds would crystallize. The structural characterizations have been performed using Fourier Transform InfraRed spectroscopy and X-Ray diffraction. Several Al-O-P compounds and especially $\mathrm{AlPO}_{4}$ polymorphs crystallize in these conditions. They belong to three families of aluminophosphates, and are a reliable indication of the amorphous organization of the original sample. The first one is similar to the phases that appear in the phase transition sequences of silica, the second one is composed of $\mathrm{AlPO}_{4}$-based zeolites, and the last one is characterized by the presence of aluminum in an octahedral network. The transitions between the different phases are also discussed. Finally, the water resistance of the calcined samples is improved, and the release of acidic species in the water is limited even after a calcination at low temperature.
\end{abstract}

\section{Keywords:}

Phosphoric acid; Metakaolin; Mechanisms of formation; XRD; FTIR; High Temperature; Water resistance; Amorphous network 


\section{Introduction}

Geopolymers, in their alkaline-based form, are now known since many years and are the subject of numerous studies due to their relative low cost and good mechanical performances [1]. They usually result from the dissolution of an aluminosilicate source in an alkaline silicate solution [2], leading to the formation of a tridimensional network combining $\mathrm{SiO}_{4}$ and $\mathrm{AlO}_{4}$ tetrahedra. However, recently, acid-based geopolymers are gaining an increasing interest from the scientific community. These materials are related to the phosphate cements, which have been studied for a longer time $\left[{ }^{3}\right]$. Although this subject is quite recent, several studies, especially using phosphoric acid, have indeed been carried out considering various aluminosilicate sources and different $\mathrm{Si} / \mathrm{Al}, \mathrm{Al} / \mathrm{P}$ or $\mathrm{Si} / \mathrm{P}$ ratios $[4,5,6]$. These materials exhibit remarkable mechanical properties [4] and a high temperature resistance up to $1450^{\circ} \mathrm{C}$ [7]. Moreover, a previous study [8] has stated that their properties (thermal and water resistance) are governed by their composition and synthesis temperature $[9,10]$ and can be closely related to the existence of different amorphous oxide networks in the material.

The synthesis of these acid-based geopolymers starts with the dissolution of an aluminosilicate source in an acidic medium, the most common one being phosphoric acid [11]. A recent study showed that the subsequent release of $\mathrm{Al}^{3+}$ and its reaction with $\mathrm{H}_{3} \mathrm{PO}_{4}$ then leads to the formation of Al-O-P- and Si-based networks [12]. However, the structural organization of the networks forming during the geopolymerization is not clearly defined yet. The initial reactive mixture containing aluminum, silicon and phosphorus, any phase forming in the different phase diagrams belonging to the $\mathrm{Al}_{2} \mathrm{O}_{3}-\mathrm{SiO}_{2}-\mathrm{P}_{2} \mathrm{O}_{5}$ system might indeed appear and eventually crystallize. In these binaries, some phases are however more prone to form and they will thus be described in the following.

Firstly, when considering the $\mathrm{P}_{2} \mathrm{O}_{5}-\mathrm{Al}_{2} \mathrm{O}_{3}$ binary, the addition of $\mathrm{Al}_{2} \mathrm{O}_{3}$ modifies the structure of the original phosphate glass, breaking the P-O-P bonds in favor of the more stable 
P-O-Al bonds. For low aluminum concentrations, it leads to the formation of $\mathrm{Al}\left(\mathrm{PO}_{3}\right)_{3}$, whereas $\mathrm{AlPO}_{4}$ is favored for higher aluminum concentrations [13]. In the geopolymer mixtures, it indeed seems that $\mathrm{AlPO}_{4}$ occurs when the temperature increases, as observed in previous papers [4, 11]. Various polymorphs have however been reported for different systems, such as berlinite-, cristobalite- or tridymite-type structures [14]. In the case of the $\mathrm{SiO}_{2}-\mathrm{Al}_{2} \mathrm{O}_{3}$ system, an increase of temperature up to $1000^{\circ} \mathrm{C}$ results in the crystallization of mullite $\left(3 \mathrm{Al}_{2} \mathrm{O}_{3}-2 \mathrm{SiO}_{2}\right)$, which has been observed by some authors after a high temperature treatment of acid-based geopolymers $[15,16]$. The $\mathrm{SiO}_{2}-\mathrm{P}_{2} \mathrm{O}_{5}$ binary is not encountered in a lot of cases, but the additional formation of Si-O-P networks in geopolymers was reported for some compositions $[12,17]$ and led to the crystallization of $\mathrm{SiO}_{2}$ and phosphosilicates $\left(\mathrm{SiP}_{2} \mathrm{O}_{5}[18]\right)$ in the case of high Si/P ratios [15, 19]. Finally, numerous studies [20, 21, 22, 23] have been devoted to glasses belonging to the $\mathrm{SiO}_{2}-\mathrm{Al}_{2} \mathrm{O}_{3}-\mathrm{P}_{2} \mathrm{O}_{5}$ system. Their conclusions confirm what is observed in the different binaries, namely $i$ ) the strong affinity between $\mathrm{Al}^{3+}$ and $\mathrm{P}^{5+}$, which promotes the formation of Al-O-P bonds, ii) the existence of free amorphous silica, and, iii) when the stoichiometry allows it, the formation of the unfavorable Si-O-P bonds.

The present work aims to better understand the network organization during the geopolymerization of a mixture of metakaolin and phosphoric acid, with an enhanced view at the early stages of the reaction. The reactive mixture was calcined at different times and temperatures, and then characterized by Fourier Transform InfraRed (FTIR) and X-Ray Diffraction (XRD). The goal is to be able to build acceptable structural models for the geopolymerization process that occurs in a fully disordered state at room temperature. The identified networks were compared with the water resistance of the calcined samples. 


\section{Materials and methods}

\subsection{Samples preparation}

The samples were synthesized from an ACS grade solution of $85 \mathrm{wt} \%$ of phosphoric acid produced by VWR (Radnor, USA) and the metakaolin denoted M3, produced by Imerys (Limoges, France) which was studied in previous works by Gharzouni et al. [24, 25]. Before the synthesis, kaolinite, with a $\mathrm{Si} / \mathrm{Al}$ molar ratio equal to 1 , was calcined at $750^{\circ} \mathrm{C}$ for 4 hours to obtain M3 metakaolin. Then the acid-based geopolymer was synthesized at room temperature by mixing it with phosphoric acid, keeping an $\mathrm{Al} / \mathrm{P}$ ratio of 1 . The complete synthesis procedure is described in a previous study [12]. This particular composition, with a very long consolidation time (21 days), was chosen in order to ensure a sufficient time between the measurements and the possibility to observe as many steps as possible occurring during the overall reaction. Immediately after the mixing, samples composed of the reactive mixture were taken off and thermally treated at different temperatures $\left(200,300,500,800\right.$ and $\left.1000^{\circ} \mathrm{C}\right)$ in a furnace with a $5^{\circ} \mathrm{C} \cdot \mathrm{min}^{-1}$ slope and a $1 \mathrm{~h}$ dwelling time. This experimental procedure was repeated at different stages of the reaction $(0,2,5,10,15,20$ and 25 days). Figure 1 represents a graphical overview of the selected samples, highlighting which samples were used for the two studies presented in this paper. The first one is the characterization of the early stages of geopolymerization whereas the second concerns the time and temperature dependency for the crystallization of phases. The heat-treated samples were systematically hand-ground in an agate mortar for the structural characterizations, and kept in their bulk form for the estimation of their water resistance. 


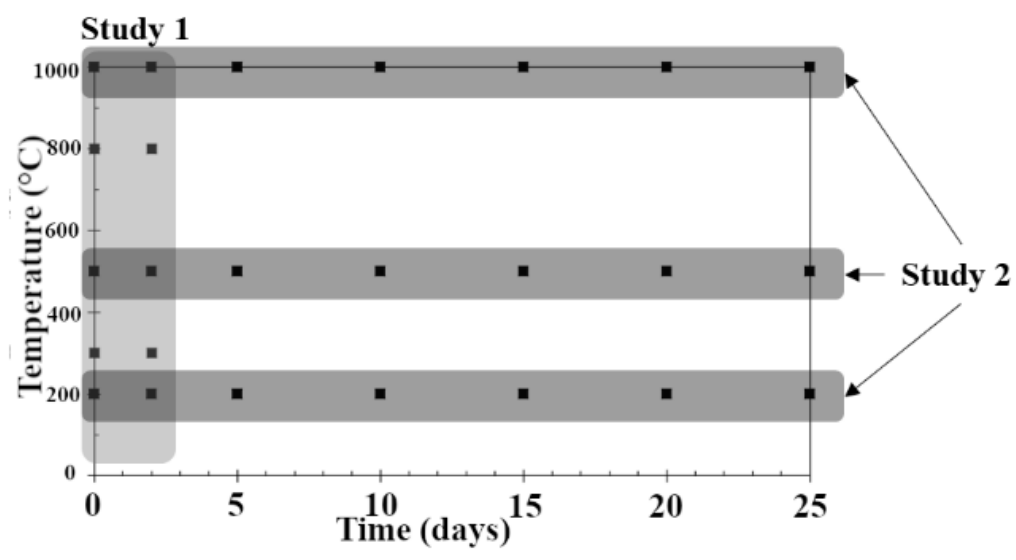

Figure 1: various consolidation times and temperatures used for the thermal treatment of the reactive mixture.

\subsection{Samples characterization}

The XRD patterns were recorded with a Bruker D8 Advance diffractometer using $\mathrm{CuK}_{\alpha}$ radiation. The acquisitions were carried out with a $2 \theta$-angle varying from 5 to $60^{\circ}$ with a step size of $0.02^{\circ}$ and an equivalent time per step of $50 \mathrm{~s}$. Their analysis was then performed using the powder diffraction file (PDF) database of the International Center for Diffraction Data to determine the various crystalline phases occurring within the samples. The list of the crystalline phases identified in this work, along with their notation in this paper, is given in Table 1. The decomposition of the diagrams was conducted using the Peakoc software [26] in order to extract the contributions from both crystalline and amorphous phases in the consolidating binder. The refinement was done between 5 and $60^{\circ}$ using a Voigt function that takes into account the $\mathrm{CuK} \alpha_{1}$ and $\mathrm{CuK} \alpha_{2}$ wavelengths of the XRD source. In addition, the continuous background was fitted with a $2^{\text {nd }}$ order polynomial. 
Table 1: List of the crystalline phases discussed in this paper.

\begin{tabular}{ccccc}
\hline Name & $\begin{array}{c}\text { Chemical } \\
\text { Formula }\end{array}$ & $\begin{array}{c}\text { Cristal } \\
\text { system }\end{array}$ & JCPDF & Symbol \\
& $\mathrm{AlPO}_{4}$ & Hexagonal & $01-089-4201$ & $\mathrm{~B}$ \\
Berlinite & $\mathrm{AlPO}_{4}$ & Triclinic & $00-050-0054$ & $\mathrm{~T}$ \\
Phosphotridymite & $\mathrm{AlPO}_{4}$ & Orthorhombic & $00-011-0500$ & $\mathrm{O}_{1}$ \\
Phophocristobalite & $\mathrm{Al}_{12} \mathrm{P}_{12} \mathrm{O}_{48}$ & Orthorhombic & $00-041-0566$ & $\mathrm{O}_{2}$ \\
Aluminum phosphate & $\mathrm{Al}_{16} \mathrm{P}_{16} \mathrm{O}_{64}$ & Orthorhombic & $00-041-0562$ & $\mathrm{O}_{3}$ \\
Aluminum phosphate & $\mathrm{Al}_{\left(\mathrm{PO}_{3}\right)_{3}}$ & Hexagonal & $00-015-0364$ & $\mathrm{H}$ \\
Aluminum phosphate & & Monoclinic & $01-089-4201$ & $\mathrm{Hy}$ \\
hydroxyde & $\mathrm{AlPO}_{3} \mathrm{O}_{8}(\mathrm{OH})_{2}$ & & & $\mathrm{Q}$ \\
Quartz & $\mathrm{SiO}_{2}$ & Trigonal & $00-046-1045$ & $\mathrm{~A}$ \\
Anatase & $\mathrm{TiO}_{2}$ & Tetragonal & $00-021-1272$ & \\
\hline
\end{tabular}

Fourier-transform infrared spectroscopy spectra of the samples, mixed in $\mathrm{KBr}$, were recorded in transmittance mode on a ThermoFisher Scientific Nicolet 380 infrared spectrometer. The IR spectra were recorded after 64 scans over a range of 400 to $4000 \mathrm{~cm}^{-1}$ with a resolution of $4 \mathrm{~cm}^{-1}$. The data were analyzed on the OMNIC software provided by Nicolet Instrument.

A selection of heat-treated samples was immersed in deionized water with a liquid/solid volume ratio equal to 15 . The $\mathrm{pH}$ value of the water, originally at 6.5 , was measured after 1 day with a pHmeter. Then the external visual aspect of the samples was observed after 7 days of static immersion in water: if coarse cracks or disaggregation could be observed on a specimen, it was classified into non-resistant group, whereas if no defect was visible, the specimen was classified into the water-resistant category. 


\section{Results}

\subsection{Description of the samples before heating}

The full study of the consolidation of the sample at room temperature was previously published [12]. However, for an easier comprehension of the present results, a brief summary of the sample's characteristics at room temperature will be given here. During the geopolymerization, the evolution from the reactive mixture, e.g. metakaolin and phosphoric acid, to the consolidated sample, can be followed by XRD and FTIR. It can be done, as shown for example in Figure 2, by detecting specific contributions and studying their respective intensity in the diagram. In this case, the first contribution is present in the metakaolin and progressively disappears while the second one is increasing its intensity. The same was observed with FTIR.

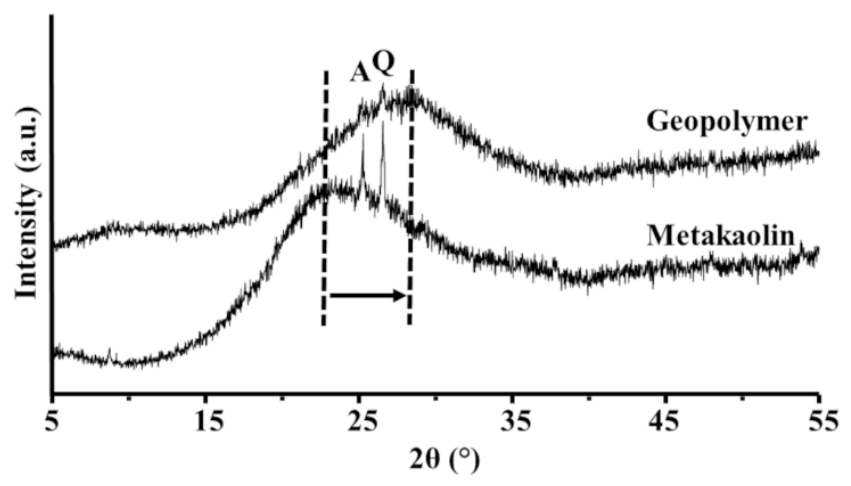

Figure 2 : Diffraction diagrams of the metakaolin and the consolidated geopolymer.

Associated with a Nuclear Magnetic Resonance (NMR) spectroscopy study $\left({ }^{31} \mathrm{P},{ }^{29} \mathrm{Si}\right.$, ${ }^{27} \mathrm{Al}$ ), the main networks of the geopolymer were identified. After the dissolution of the metakaolin and the bonds formations, it is indeed composed of Al-O-P networks, with minor contributions of Si-O, Si-OH and Si-O-P. After heating, the Al-O-P part of the sample crystallizes, while the silicate part remains unchanged. 


\subsection{Study 1: early stages of the geopolymerization ( 0 and 2 days)}

The first temperature dependent study was focused on the very early stages of geopolymerization, i.e. immediately after the mixing of the reagents ( 0 day) and at the beginning of the reaction ( 2 days). Each sample was calcined at $200,300,500,800$ and $1000^{\circ} \mathrm{C}$, crushed into powder in an agate mortar and pestle, and then characterized by FTIR and XRD. Figure 3 and Figure 4 present the obtained results. For the ease of reading, only the 600 to 1400 $\mathrm{cm}^{-1}$ part of the FTIR spectra are presented here as it corresponds to the characteristic wavenumbers of the metal-oxygen bonds. The corresponding full spectra are available in supplementary material (S1 and S2).

First, the FTIR spectra of the original mixture, calcined at different temperatures, are shown in Figure 3a. For the lowest temperature treatment, i.e. at $200^{\circ} \mathrm{C}$, five contributions are observed at 1199, 1092, 984, 802 and $669 \mathrm{~cm}^{-1}$ and attributed to Si-O-Si [27], P-O [28], P-O from $\mathrm{H}_{2} \mathrm{PO}_{4}{ }^{2-}$ [29], Si-O-Si [30] and O-Si-O [31], respectively. All of these bands correspond to the reagents, testifying that the reaction has hardly begun at this stage. With the increase of the temperature $\left(300^{\circ} \mathrm{C}\right.$ and $\left.500^{\circ} \mathrm{C}\right)$, and the subsequent increase of the energetic input, new bands appear at 1286, 974 and $926 \mathrm{~cm}^{-1}$ and are attributed to $\mathrm{Al}\left(\mathrm{PO}_{3}\right)_{3}$ [32] compounds, and $\mathrm{Al}-\mathrm{OH}-\mathrm{Al}$ bonds [33] for the last one. When the temperature reaches $800^{\circ} \mathrm{C}$, the $\mathrm{Al}\left(\mathrm{PO}_{3}\right)_{3}$ signature disappears and is replaced by contributions from two different $\mathrm{AlPO}_{4}$ polymorphs [34] $\left(1232 \mathrm{~cm}^{-1}\right.$ and $1113 \mathrm{~cm}^{-1}$ corresponding respectively to the orthorhombic and the triclinic forms). Finally, at $1000^{\circ} \mathrm{C}$, the formation of the two $\mathrm{AlPO}_{4}$ polymorphs is complete $\left(1121 \mathrm{~cm}^{-}\right.$

${ }^{1}$ for the triclinic and $1232,728,712 \mathrm{~cm}^{-1}$ for the orthorhombic [34]). In addition, $\mathrm{P}=\mathrm{O}(1321$ $\left.\mathrm{cm}^{-1}[35]\right)$ and Si-O-P $\left(1188 \mathrm{~cm}^{-1}[36]\right)$ bonds are evidenced at $1000^{\circ} \mathrm{C}$. These compounds were already identified by a joint FTIR and NMR spectroscopy in a previous study [37]. 


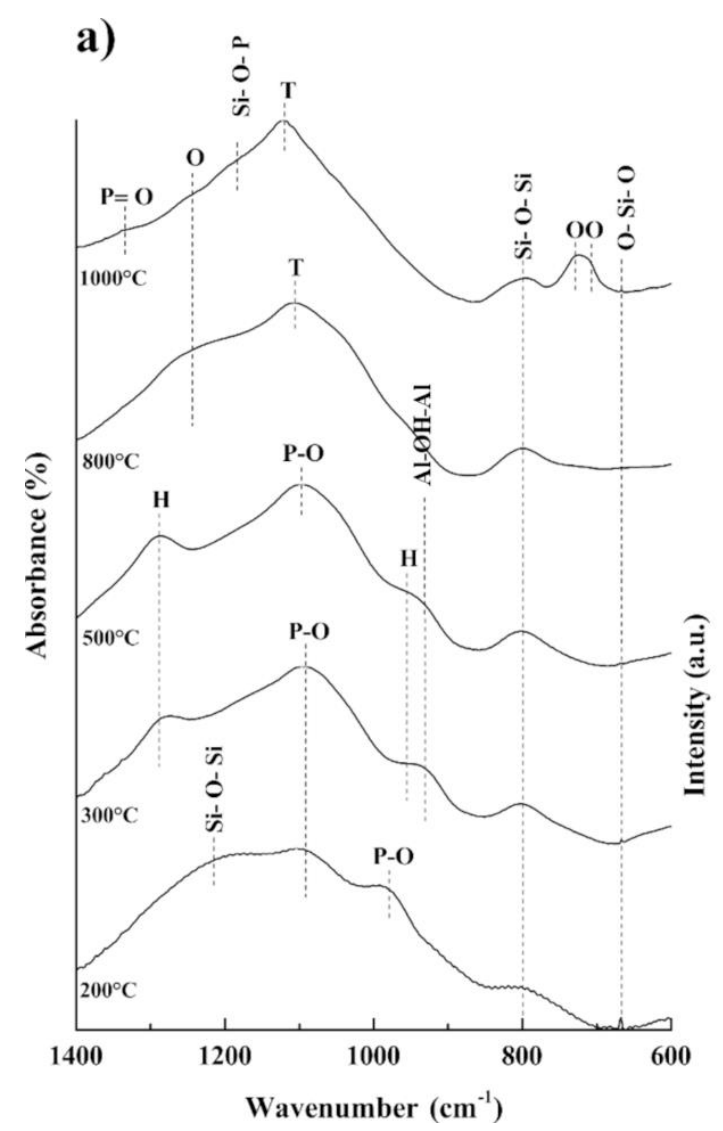

b)

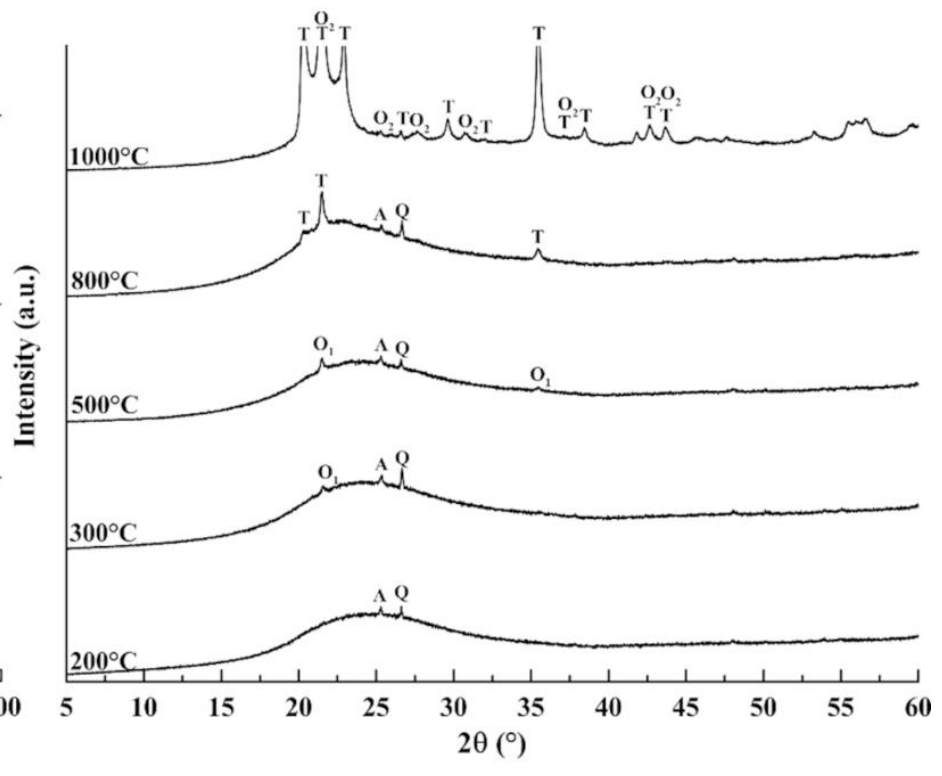

Figure 3: a) FTIR and b) XRD measurements of 0 day-aged reactive mixture thermally treated at $200,300,500,800$ and $1000^{\circ} \mathrm{C}$. See Table 1 for the peaks attribution.

These results are in good agreement with the XRD study as shown in Figure 3b. First, all the samples display weak contributions of quartz and anatase, originating from the starting metakaolin. Apart from these crystallized minerals, the sample is amorphous at $200^{\circ} \mathrm{C}$ and only a very broad contribution is visible at approximately $25^{\circ}$. Peaks from orthorhombic $\mathrm{AlPO}_{4}$ start to emerge at $300^{\circ} \mathrm{C}$ and are clearly visible at $500^{\circ} \mathrm{C}$. In addition, triclinic $\mathrm{AlPO}_{4}\left(\mathrm{O}_{1}\right)$ is formed at $800^{\circ} \mathrm{C}$, while the orthorhombic polymorph is overlapped due to this scarce presence. Finally, at $1000^{\circ} \mathrm{C}$, orthorhombic $\mathrm{Al}_{12} \mathrm{P}_{12} \mathrm{O}_{48}\left(\mathrm{O}_{2}\right)$ and triclinic $\mathrm{AlPO}_{4}(\mathrm{~T})$ are well crystallized, while the amorphous part of the sample tends to disappear. $\mathrm{The} \mathrm{Al}\left(\mathrm{PO}_{3}\right)_{3}(\mathrm{H})$ polymorph, although 
detected by FTIR, is not seen here. The long-range organization of this phase is probably not sufficient to generate peaks of sufficient intensity.

After a calcination at $200^{\circ} \mathrm{C}$, the FTIR spectrum of the 2-days old sample (Figure 4a) is characterized by bands at $1097 \mathrm{~cm}^{-1}(\mathrm{P}-\mathrm{O}), 802 \mathrm{~cm}^{-1}$ (Si-O-Si) and $669 \mathrm{~cm}^{-1}$ (O-Si-O), which were previously identified in the 0-day sample. Additional bands, however, appear at $1232 \mathrm{~cm}^{-}$ ${ }^{1}$ and $926 \mathrm{~cm}^{-1}$ and correspond to the orthorhombic form of $\mathrm{AlPO}_{4}$ and $\mathrm{Al}-\mathrm{OH}-\mathrm{Al}$ bonds, respectively. At 300 and $500^{\circ} \mathrm{C}$, the predominant formation of $\mathrm{Al}\left(\mathrm{PO}_{3}\right)_{3}$ is visible with clear contributions at 1286 and $974 \mathrm{~cm}^{-1}$. Their presence may overlap the possible position of orthorhombic $\mathrm{AlPO}_{4}$, making its presence unclear, but the contributions of the other bonds are still visible. With the increase of the temperature to $800^{\circ} \mathrm{C}, \mathrm{Al}\left(\mathrm{PO}_{3}\right)_{3}$ contributions and $\mathrm{Al}-\mathrm{OH}-$ Al bonds disappear and orthorhombic $\mathrm{AlPO}_{4}$ is visible again at 1232, 728 and $712 \mathrm{~cm}^{-1}$, indicating that it was probably also present at lower temperatures. Moreover, bands from triclinic $\mathrm{AlPO}_{4}\left(1121 \mathrm{~cm}^{-1}\right)$ as well as Si-O-P bonds $\left(1188 \mathrm{~cm}^{-1}\right)$ are identified. Finally, at $1000^{\circ} \mathrm{C}, \mathrm{P}=\mathrm{O}\left(1321 \mathrm{~cm}^{-1}\right)$ and a few berlinite (hexagonal $\left.\mathrm{AlPO}_{4}\right)\left(650\right.$ and $\left.625 \mathrm{~cm}^{-1}\right)$ bonds are formed in addition to the previous ones [33].

The identification of crystalline phases by XRD (Figure 4b) is coherent with FTIR. Peaks from the orthorhombic polymorph of $\mathrm{AlPO}_{4}\left(\mathrm{O}_{1}\right)$ can be seen in the $200^{\circ} \mathrm{C}$ to $800^{\circ} \mathrm{C}$ temperature range. From $800^{\circ} \mathrm{C}$, the triclinic polymorph of $\mathrm{AlPO}_{4}(\mathrm{~T})$ is formed and at $1000^{\circ} \mathrm{C}$

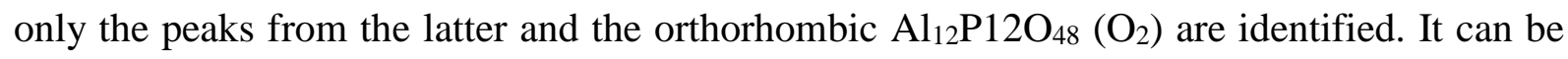
noted that the phase corresponding to Al-OH-Al bonds, $\mathrm{Al}\left(\mathrm{PO}_{3}\right)_{3}(\mathrm{H})$ and the berlinite (B) observed on FTIR spectra could not be detected, probably due to their low volume fraction in the sample or highly disordered nature. 


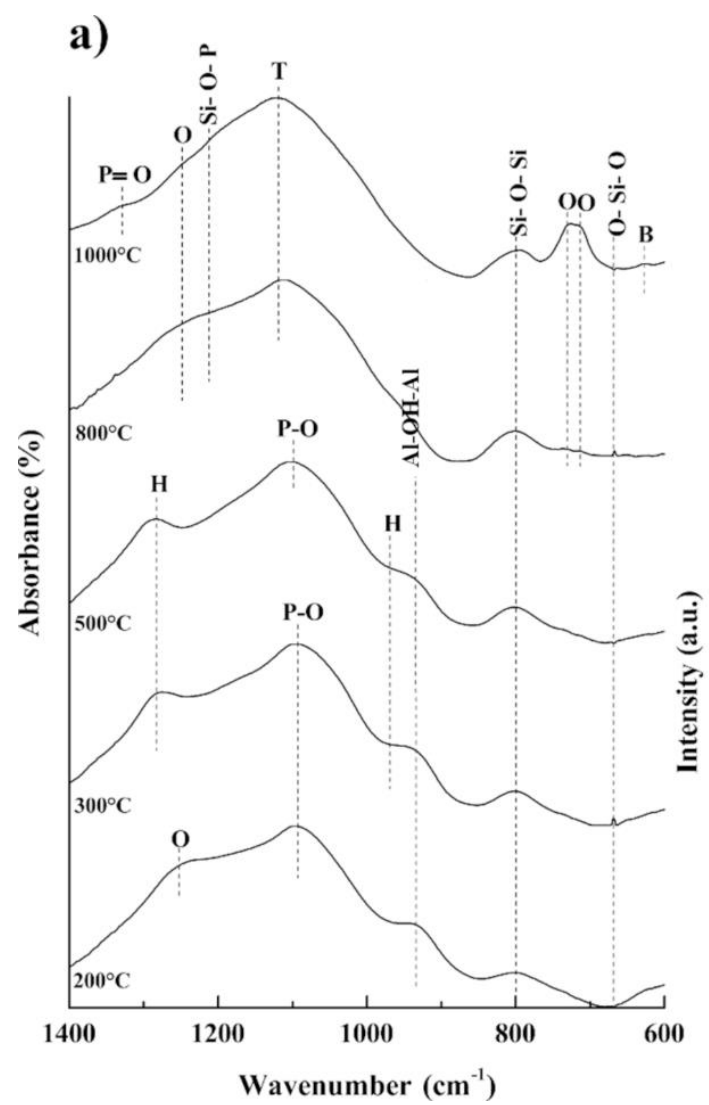

\section{b)}

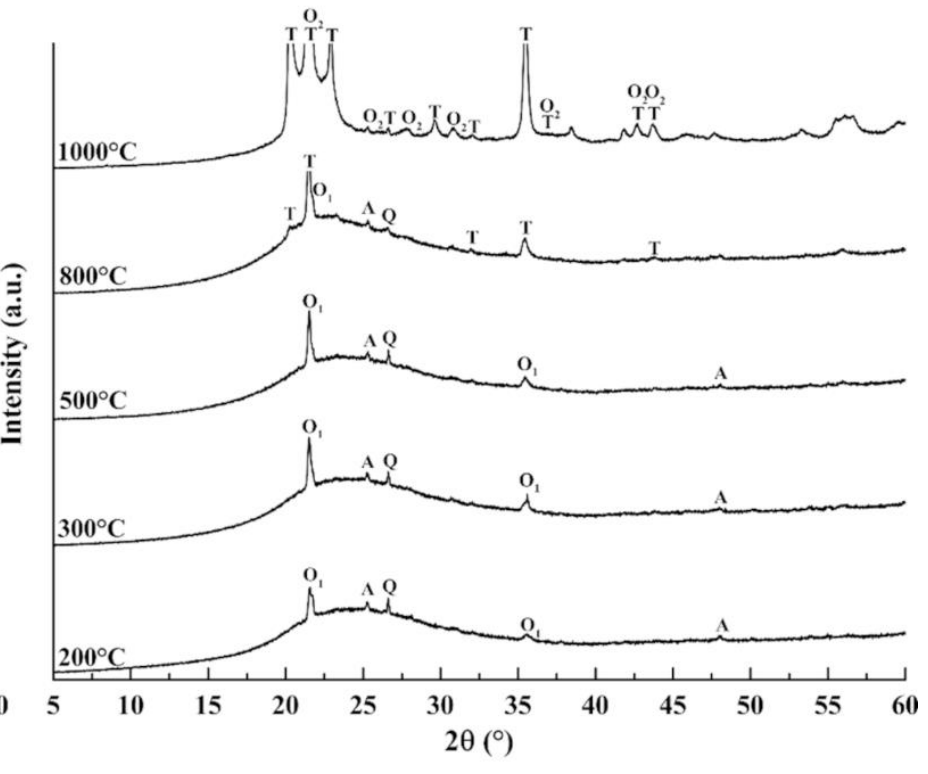

Figure 4: a) FTIR and b) XRD measurements of 2 days-aged reactive mixture, thermally treated at $200,300,500,800$ and $1000^{\circ} \mathrm{C}$. See Table 1 for the peaks attribution.

To summarize, in the first steps of the geopolymerization ( 0 and 2 days), the predominant identified compounds are $\mathrm{Al}\left(\mathrm{PO}_{3}\right)_{3}$ and orthorhombic $\mathrm{AlPO}_{4}\left(\mathrm{O}_{1}\right)$ at low temperature (200 to $\left.500^{\circ} \mathrm{C}\right)$. With the increase of the temperature, $\mathrm{Al}\left(\mathrm{PO}_{3}\right)_{3}$ and $\mathrm{AlPO}_{4}\left(\mathrm{O}_{1}\right)$ disappear, and triclinic $\mathrm{AlPO}_{4}(\mathrm{~T})$ is formed from $800^{\circ} \mathrm{C}$ and $\mathrm{Al}_{12} \mathrm{P}_{12} \mathrm{O}_{48}\left(\mathrm{O}_{2}\right)$ at $1000^{\circ} \mathrm{C}$. Finally, large amounts of disordered material remain in the sample, with the exception of the ones calcined at $1000^{\circ} \mathrm{C}$. 


\subsection{Study 2: formation of partially organized networks}

In order to follow the crystallization of the different phases in the sample until its complete consolidation, estimated at 21 days [12], additional samples of the reactive mixture were considered for different reaction times $(0,2,5,10,15,20$ and 25 days) and calcined at 200,500 and $1000^{\circ} \mathrm{C}$. The XRD diagrams of the calcined materials are presented in Figure 5 . At $200^{\circ} \mathrm{C}$ (Figure 5a), whatever the duration, the sample always contains a part of amorphous phase, visible by the broad contribution centered at approximately $25^{\circ}$. No crystalline phase appears at 0 day, with the exception of quartz and anatase originating from the M3 metakaolin, which are visible in all the diffractograms. Then, the orthorhombic polymorph of $\mathrm{AlPO}_{4}\left(\mathrm{O}_{1}\right)$ appears from 2 days. The intensity of its contributions increases up to 5 days, then becomes less preponderant, and slowly decreases from 10 to 25 days. This decrease is concomitant with both the emergence of $\mathrm{AlP}_{3} \mathrm{O}_{8}(\mathrm{OH})_{2}(\mathrm{Hy})$ and the increasing presence of berlinite $(\mathrm{B})$, the hexagonal polymorph of $\mathrm{AlPO}_{4}$ that starts to crystallize in the 5-days sample. When the sample is fully solidified (25 days), berlinite is the predominant phase with minor contributions from orthorhombic $\mathrm{AlPO}_{4}$ and $\mathrm{AlP}_{3} \mathrm{O}_{8}(\mathrm{OH})_{2}$.

At $500^{\circ} \mathrm{C}$ (Figure 5b), as seen previously the orthorhombic polymorph of $\mathrm{AlPO}_{4}\left(\mathrm{O}_{1}\right)$ crystallizes in the 0-day sample. The intensities of the related peaks then increase until 5 days and then remain stable afterwards. Contrarily to what happens at $200^{\circ} \mathrm{C}, \mathrm{Al}\left(\mathrm{PO}_{3}\right)_{3}(\mathrm{H})$ appears with a weak intensity after 2 days. At this temperature, it is visible but remains with a very low intensity for longer consolidation times. $\mathrm{AlP}_{3} \mathrm{O}_{8}(\mathrm{OH})_{2}(\mathrm{Hy})$ is identified from 5 days until the complete geopolymerization reaction. Moreover, at this temperature and starting at 5 days, a new orthorhombic aluminophosphate, with the composition $\mathrm{Al}_{16} \mathrm{P}_{16} \mathrm{O}_{64}\left(\mathrm{O}_{3}\right)$, is formed. The intensities of its contributions increase with the consolidation time and stay stable from 15 days on. Finally, after a $500^{\circ} \mathrm{C}$ thermal treatment, the fully consolidated sample (25 days) contains a 
mixture of the orthorhombic $\mathrm{AlPO}_{4}, \mathrm{Al}_{16} \mathrm{P}_{16} \mathrm{O}_{64}$ and berlinite-type $\mathrm{AlPO}_{4}$ as majority phases, with the contribution of $\mathrm{AlP}_{3} \mathrm{O}(\mathrm{OH})_{2}$ as a minority phase and a very weak signature of $\mathrm{Al}\left(\mathrm{PO}_{3}\right)_{3}$.

At $1000^{\circ} \mathrm{C}$ (Figure 5c), the amount of amorphous phase in the sample is barely noticeable. Starting at 0 days, all the samples contain two crystalline aluminophosphate compounds, namely triclinic $\mathrm{AlPO}_{4}(\mathrm{~T})$ and the orthorhombic $\mathrm{Al}_{12} \mathrm{P}_{12} \mathrm{O}_{48}\left(\mathrm{O}_{2}\right)$. Their intensities remain stable within the ageing of the reactive mixture. Starting at 5 days, the berlinite-type polymorph of $\mathrm{AlPO}_{4}$ appears but keeps a relatively low intensity. Finally, when fully consolidated, the predominant phase is the triclinic polymorph $\mathrm{AlPO}_{4}$, with lower contributions from $\mathrm{Al}_{12} \mathrm{P}_{12} \mathrm{O}_{48}$ and berlinite-type $\mathrm{AlPO}_{4}$. 
a)

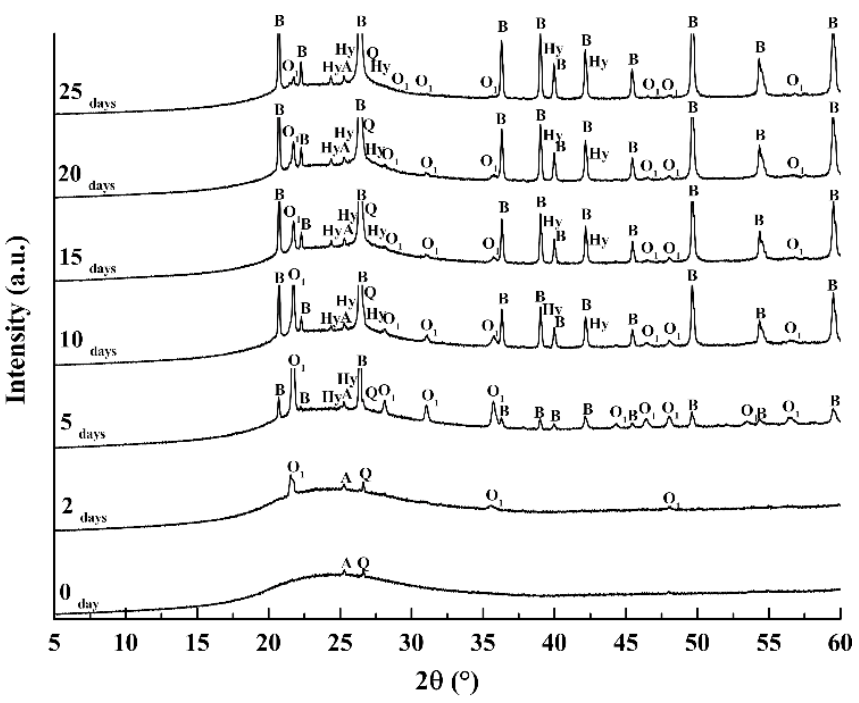

b)

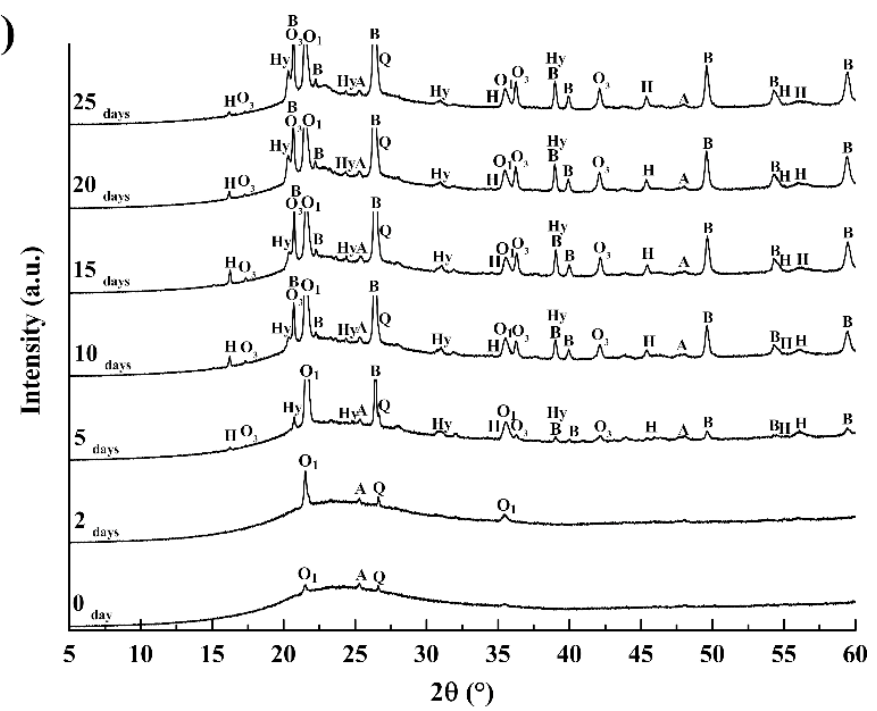

c)

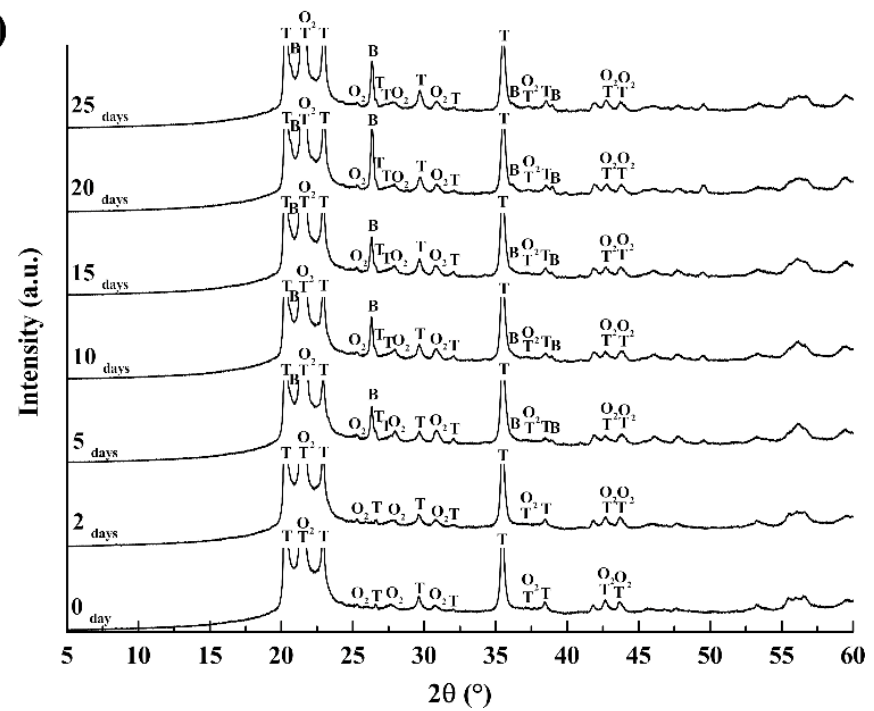

Figure 5: XRD diagrams of the reactive mixture thermally treated at (a) 200, (b) 500, and (c) $1000^{\circ} \mathrm{C}$ for consolidation times of 0, 5, 10, 15, 20 and 25 days. See Table 1 for the peaks 
The XRD measurements were complemented by a systematic FTIR spectroscopy analysis, whose results are presented in Figure 6. As stated previously, only the 600 to 1400 $\mathrm{cm}^{-1}$ part of the FTIR spectra are presented here, the full spectra being available in supplementary material (S3, S4 and S5). Firstly, at $200^{\circ} \mathrm{C}$, the evolution of the presence of the orthorhombic polymorph of $\mathrm{AlPO}_{4}$ is confirmed by the intensity of its band situated at 1232 $\mathrm{cm}^{-1}$ as shown in Figure 6a. The band at $926 \mathrm{~cm}^{-1}$, corresponding to Al-OH-Al bonds is in agreement with the presence of $\mathrm{AlP}_{3} \mathrm{O}_{8}(\mathrm{OH})_{2}$. However, contrarily to what was observed by $\mathrm{XRD}$, this compound is identified as soon as 2 days after the preparation of the reactive mixture. Moreover, the occurrence of the berlinite-type $\mathrm{AlPO}_{4}$ from 5 days on, whose contribution strengthens with time, is confirmed by the increasingly intense bands at 749, 706, 698 and 650 $\mathrm{cm}^{-1}$ [32]. Secondly, at $500^{\circ} \mathrm{C}$ (Figure 6b), there is a clear contribution of $\mathrm{Al}\left(\mathrm{PO}_{3}\right)_{3}$, in the FTIR spectra, with bands at 1112, 749, 732, 706, 698 and $650 \mathrm{~cm}^{-1}$ [32] visible from 5 days on. The presence of berlinite-type $\mathrm{AlPO}_{4}$ is also confirmed by its well-defined contributions in the same time range. Moreover, $\mathrm{AlP}_{3} \mathrm{O}_{8}(\mathrm{OH})_{2}$, represented by $\mathrm{Al}-\mathrm{OH}-\mathrm{Al}$ bonds $\left(926 \mathrm{~cm}^{-1}\right)$ is also visible on all the spectra, although it was difficult to observe in XRD due to its low proportion in the sample. No clear signature from the orthorhombic phases, namely $\mathrm{Al}_{16} \mathrm{P}_{16} \mathrm{O}_{64}\left(\mathrm{O}_{3}\right)$ and orthorhombic $\mathrm{AlPO}_{4}\left(\mathrm{O}_{1}\right)$ were evidenced in the FTIR spectra as they are probably overlapped by other contributions due to the similarities of the considered structures. Finally, at $1000^{\circ} \mathrm{C}$, the strong presence of triclinic $\mathrm{AlPO}_{4}\left(1121 \mathrm{~cm}^{-1}\right)$ and orthorhombic $\mathrm{Al}_{12} \mathrm{P}_{12} \mathrm{O}_{48}(1232,728$, $\left.712 \mathrm{~cm}^{-1}\right)$, as well as weak contribution of berlinite-type $\mathrm{AlPO}_{4}\left(650,625 \mathrm{~cm}^{-1}\right)$ were confirmed, the triclinic $\mathrm{AlPO}_{4}$ being the most visible. Moreover, $\mathrm{P}=\mathrm{O}$ and $\mathrm{Si}-\mathrm{O}-\mathrm{P}$ bonds are observed similarly to our previous study [37]. 
a)

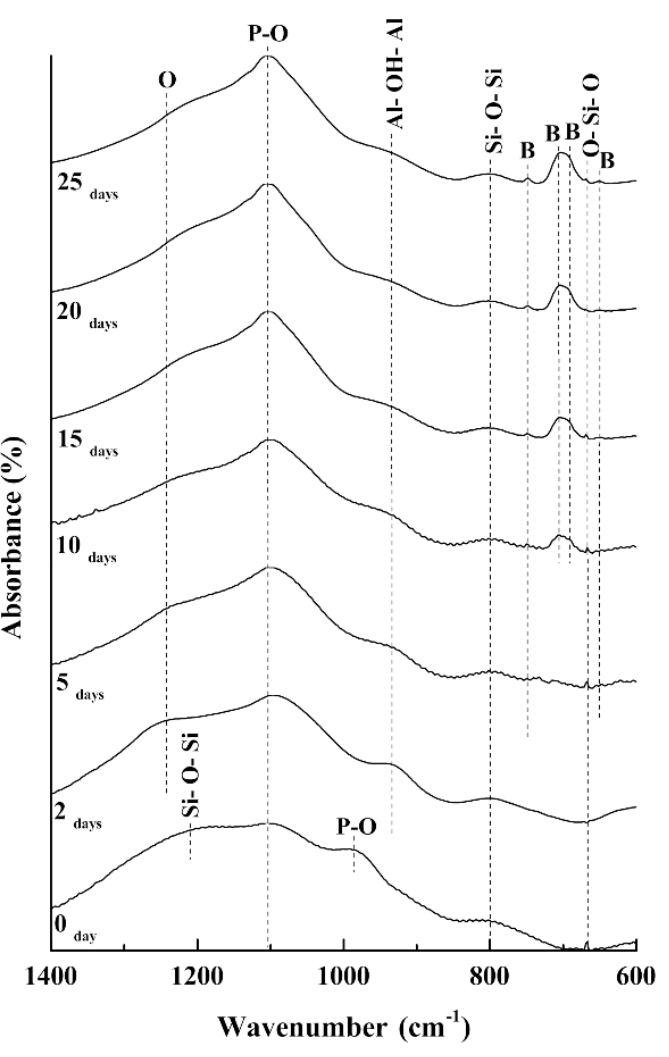

b)

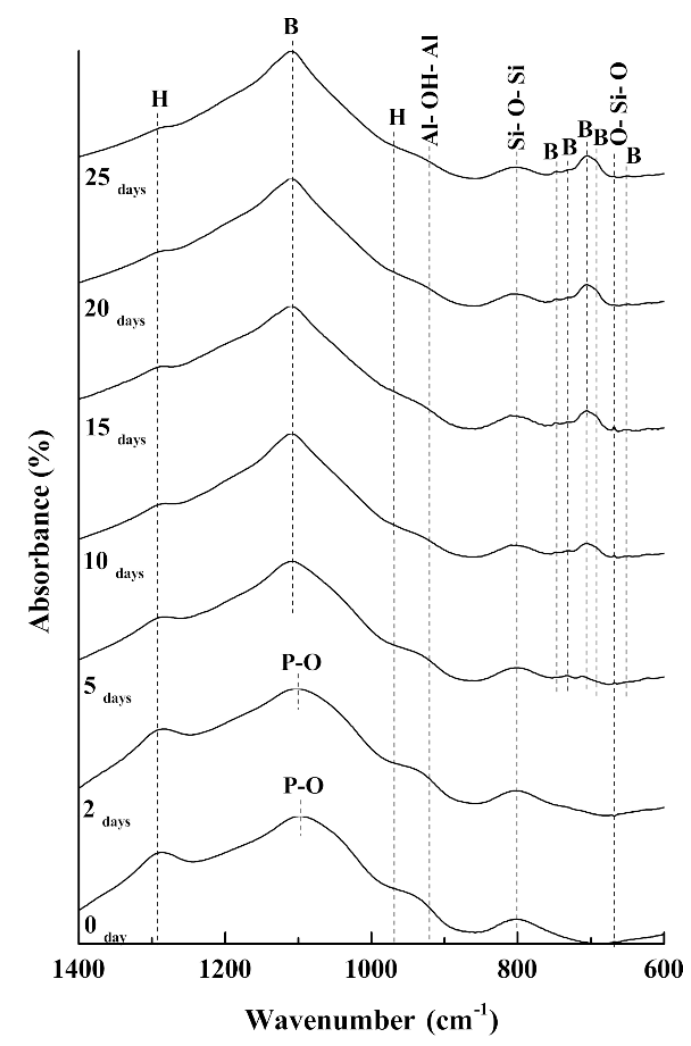

c)

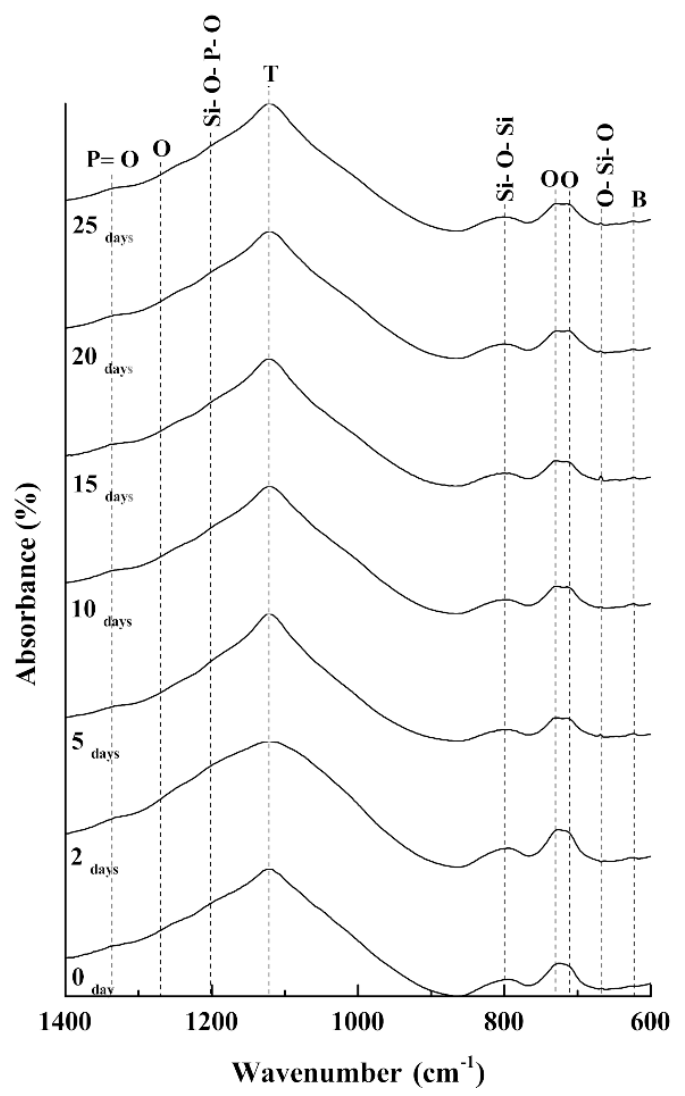

Figure 6: FTIR results of reactive mixture thermally treated at a) 200, b) 500, and c) $1000^{\circ} \mathrm{C}$ aged of $0,5,10,15,20$ and 25 days. 


\section{Discussion}

In this study, the crystalline phases identified are mainly composed of aluminum and phosphorus. In order to verify this assumption, as the reagents also contain silicon, the decomposition of the XRD contributions of the silica-based network (S) and of the geopolymerbased network $(\mathrm{G})$ was performed. The method used is described in a previous work [12] and an example of the results is presented in Figure 7. It shows the results obtained for the reactive mixture ( 0 day), calcined at $200^{\circ} \mathrm{C}$ (amorphous) and $800^{\circ} \mathrm{C}$ (amorphous and crystalline). If we define $I_{S}$ as the intensity of the Si-based network contribution and $I_{G}$ the intensity of the geopolymer-based network contribution, the evolution of the $\mathrm{I}_{\mathrm{G}} / \mathrm{I}_{\mathrm{S}}$ ratio gives an information about the type of network that crystallizes while the other tends to remain amorphous. This ratio changes from 6.6 to 2.6 , indicating that the amorphous Si-based network is not modified at the first stages of the reaction. For the fully crystallized samples, since Al-Si-O and Al-P-O compounds are isostructural, the original aluminophosphate compounds were considered.

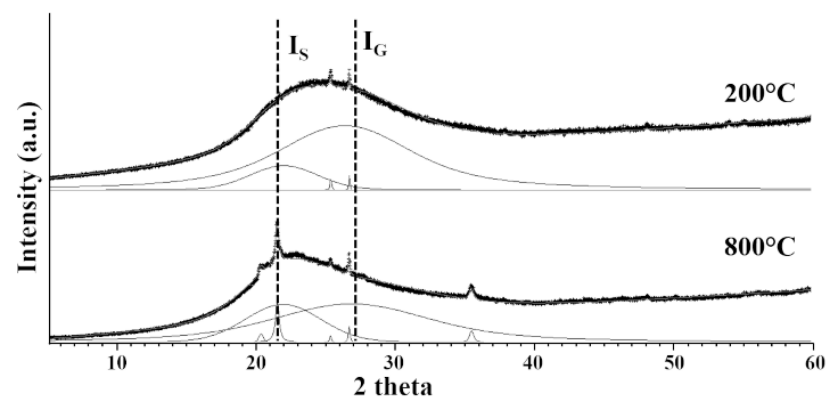

Figure 7: Decomposition of the different contributions in the XRD diagrams measured after the calcination of the reactive mixture at 200 and $800^{\circ} \mathrm{C}$.

The identified crystalline structures, most of which belong to the zeolites family, have already been refined by other authors, and they are listed in Table 2, including some structural data and cif file references. From a structural point of view, they can be divided into three main 
categories. The first one, being berlinite-type [38], triclinic tridymite-type [39] and orthorhombic $\mathrm{AlPO}_{4}$ [40] show some up-down-up-down structures made of an alternation of corner sharing $\mathrm{AlO}_{4}$ and $\mathrm{PO}_{4}$ tetrahedra [41]. They are described as strict 6-ring structures, and are analogous of the polymorphs of silica. The level of distortion of these structures defines the symmetry of the phase. The second group, with $\mathrm{Al}_{12} \mathrm{P}_{12} \mathrm{O}_{48}$ [42] and $\mathrm{Al}_{16} \mathrm{P}_{16} \mathrm{O}_{64}$ [43] zeolitetype structures, is made of 8-rings structures of corner sharing $\mathrm{AlO}_{4}$ and $\mathrm{PO}_{4}$ tetrahedra, linked together by smaller 4-rings or 4+6-rings entities. Chains alternating aluminum and phosphorus cations characterize them both. When previously studied, they were synthesized by the thermal treatment and dehydration of hydrated $\mathrm{AlPO}_{4}$ prepared by hydrothermal synthesis [44], similarly to $\mathrm{AlP}_{3} \mathrm{O}_{8}(\mathrm{OH})_{2}$. Finally, $\mathrm{Al}\left(\mathrm{PO}_{3}\right)_{3}$ [45] and $\mathrm{AlP}_{3} \mathrm{O}_{8}(\mathrm{OH})_{2}$ [46], consist in structures made of corner sharing $\mathrm{AlO}_{6}$ octahedra and $\mathrm{PO}_{4}$ tetrahedra. Concerning the phosphate part of the structures, $\mathrm{Al}\left(\mathrm{PO}_{3}\right)_{3}$ is characterized by $\mathrm{P}_{4} \mathrm{O}_{8}$ groups while the other one exhibits some open $\mathrm{P}_{3} \mathrm{O}_{10}$ phosphates structural units. Moreover, in both cases the $\mathrm{AlO}_{6}$ are isolated from each other and only connect to $\mathrm{PO}_{4}$.

Table 2: List of the identified crystalline phases, including some of their structural data.

\begin{tabular}{ccccccc}
\hline Symbol & Formula & $\begin{array}{c}\text { ICSD } \\
\text { reference }\end{array}$ & $\begin{array}{c}\text { Alternate } \\
\text { name }\end{array}$ & $\begin{array}{c}\text { Al } \\
\text { coordination }\end{array}$ & $\begin{array}{c}\text { Rings } \\
\text { structure }\end{array}$ & Reference \\
\hline $\mathrm{B}$ & $\mathrm{AlPO}_{4}$ & 44880 & Berlinite & {$[4]$} & 6 & {$[38]$} \\
$\mathrm{T}$ & $\mathrm{AlPO}_{4}$ & 280307 & Tridymite & {$[4]$} & 6 & {$[39]$} \\
$\mathrm{O}_{1}$ & $\mathrm{AlPO}_{4}$ & 97546 & - & {$[4]$} & 6 & {$[40]$} \\
$\mathrm{O}_{2}$ & $\mathrm{Al}_{12} \mathrm{P}_{12} \mathrm{O}_{48}$ & 108832 & $\mathrm{AlPO}_{4}-25$ & {$[4]$} & $8+4$ & {$[42]$} \\
$\mathrm{O}_{3}$ & $\mathrm{Al}_{16} \mathrm{P}_{16} \mathrm{O}_{64}$ & 69358 & $\mathrm{AlPO}_{4}-\mathrm{D}$ & {$[4]$} & $8+6+4$ & {$[43]$} \\
$\mathrm{H}$ & $\mathrm{Al}_{(}\left(\mathrm{PO}_{3}\right)_{3}$ & 409479 & - & {$[6]$} & none & {$[45]$} \\
$\mathrm{Hy}$ & $\mathrm{AlPO}_{3} \mathrm{O}_{8}(\mathrm{OH})_{2}$ & 39432 & - & {$[6]$} & none & {$[46]$} \\
\hline
\end{tabular}


Figure 8 summarizes all the phases identified in the samples, with the exception of Figure 8e, which recalls which samples have been synthesized. For each of them, the intensity of the black color of the dots represents the intensity of their contribution to the diagram, and the continuous grey area highlights the samples for which this phase is predominant. First, considering the 6-rings structures (Figure 8a, b and c), phases of different symmetry were identified in every diagram. At short times and low temperature, the slightly distorted $\mathrm{O}_{1}$ phase briefly dominates, but is replaced, still for low temperatures, by a better organized B phase starting at 10 days. This reorganization can be the reason of the slight modification of the geopolymerization rate that was observed at 11 days in a previous study performed on the same sample [12]. Such a transformation was also observed by Kominami et al. [47] during a high temperature hydrolysis in an organic solvent. The formation of the metatstable phase evolving into berlinite was then attributed to a weak dissolution in the solvent used. At $1000^{\circ} \mathrm{C}$, the age of the reactive mixture is not significant, as such a high amount of energy always favors the crystallization of $\mathrm{T}$ phase. This evolution is well documented, in the phase diagram of $\mathrm{AlPO}_{4}$, as the phase transition berlinite to tridymite is reported at $815^{\circ} \mathrm{C}$ in aluminophosphates [48], which is coherent with our observations.

The second group, with the zeolite-type 8-ring structures, is represented in Figure 8d and f. Depending on the calcination temperature, two different structures are observed. At $1000^{\circ} \mathrm{C}$ (Figure $8 \mathrm{~d}$ ), $\mathrm{Al}_{12} \mathrm{P}_{12} \mathrm{O}_{48}$, with its $8+6+4$ rings network, is identified in all the diffraction diagrams, regardless of the reaction time. This phase, also known as $\mathrm{AlPO}_{4}-25$, was previously studied by Richardson et al. [42] and is the result of the temperature induced $\left(500^{\circ} \mathrm{C}\right)$ dehydration and structural reorganization of $\mathrm{AlPO}_{4}-21$. At $500^{\circ} \mathrm{C}$ another structure, $\mathrm{Al}_{16} \mathrm{P}_{16} \mathrm{O}_{64}$ (or $\mathrm{AlPO}_{4}-\mathrm{D}$ ) with its pure 8+4-rings network is more visible with the increasing reaction time (Figure 8d). Its formation and structure was studied by Keller et al. [43], from the calcination at $250^{\circ} \mathrm{C}$ of $\mathrm{AlPO}_{4}-\mathrm{C}$, which originated from the dehydration of $\mathrm{AlPO}_{4}-\mathrm{H} 3$, or from the direct 
dehydration of $\mathrm{AlPO}_{4}-\mathrm{H} 6$. AlPO4-25 and AlPO4-D share relatively similar structures, and differ mostly by their formation temperature. We can thus suppose that in the sample studied in this work, they were crystallized from the same amorphous network. Moreover, whatever the structure, no signature of the crystalline hydrated phase was evidenced, but FTIR bands corresponding to hydrated phases can be seen in Figure 6, and a part of these contributions could correspond to amorphous hydrated phases with a tetrahedral chaining close to the ones observed in $\mathrm{AlPO}_{4}-21$ or $\mathrm{AlPO}_{4}-\mathrm{H} 6$ for example. The amorphous part of the diagrams is indeed clearly visible, as shown in Figure $8 \mathrm{~h}$.
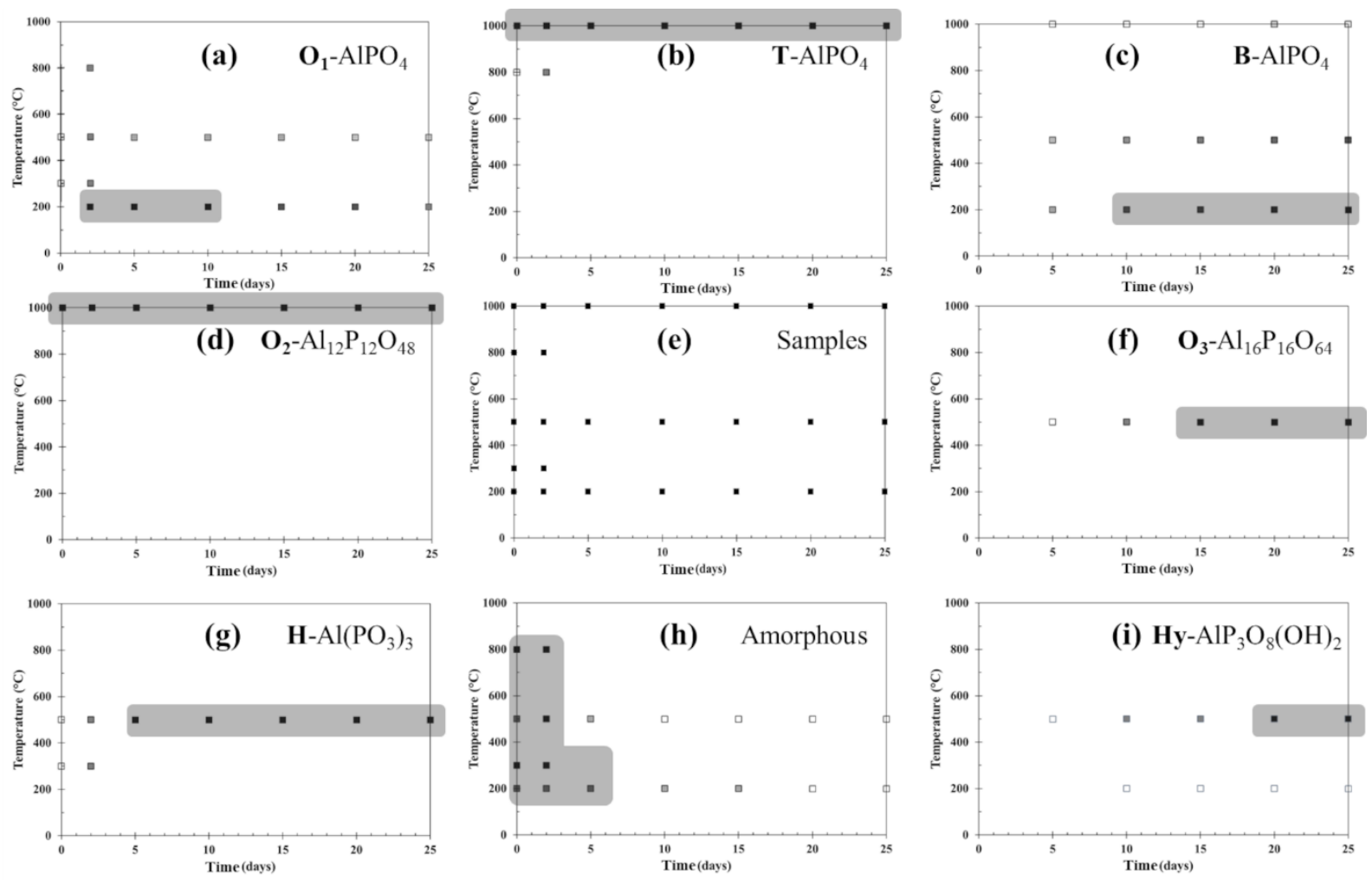

Figure 8: Predominance of each phases (a) $\mathrm{AlPO}_{4}$ orthorhombic, (b) $\mathrm{AlPO}_{4}$ triclinic, (c) $\mathrm{AlPO}_{4}$ berlinite, (d) $\mathrm{Al}_{12} \mathrm{P}_{12} \mathrm{O}_{48}$ orthorhombic, (e) general view of the synthesized samples, $(f)$ $\mathrm{Al}_{16} \mathrm{P}_{16} \mathrm{O}_{64}$ orthorhombic, (g) $\mathrm{Al}\left(\mathrm{PO}_{3}\right)_{3}$, (h) amorphous phases and (i) $\mathrm{AlP} \mathrm{P}_{3} \mathrm{O}_{8}(\mathrm{OH})_{2}$, issued by XRD following the age and the calcination temperature of 1-M3-20 samples. Black dots represent samples with a high proportion of the phase while open ones mean that the phase was barely detected. 
Finally, the remaining phases are shown in Figure $8 \mathrm{~g}$ and i. $\mathrm{Al}\left(\mathrm{PO}_{3}\right)_{3}$, with its $\mathrm{Al}^{3+}$ in 6coordination is well represented at $500^{\circ} \mathrm{C}$, whatever the age of the reactive mixture, as seen in Figure 8g. This reveals that after its dissolution in the acid, a part of the aluminum tends to keep its original octahedral neighborhood. This is also true for hydrated $\mathrm{AlP}_{3} \mathrm{O}_{8}(\mathrm{OH})_{2}$ (Figure 8i), observed as a minority phase in samples calcined at $200^{\circ} \mathrm{C}$ and $500^{\circ} \mathrm{C}$.

It is interesting to point out that, whatever the phases that crystallize, all these open structures are made of small rings, with only 4,6 or 8 entities connected, when aluminophosphate zeolites can present very large openings [49]. This is also true at low calcination temperatures when the system only received a small quantity of thermal energy. We can thus suppose that the original amorphous network is probably made of relatively compact aluminophosphate rings. Moreover, it seems that a small part of the aluminum stays in its octahedral configuration, but the majority of the reagent belongs to two types of tetrahedralbased networks that coexist in the sample, as shown by the simultaneous crystallization of silica isostructural $\mathrm{AlPO}_{4}$ polymorphs (6 rings), and zeolite-type structures based on 8 rings structures.

To verify whether these treatments would modify the properties of the geopolymer, the water resistance of the calcined samples was tested, and the $\mathrm{pH}$ value of their immersion water was measured after 1 day. The results are presented in Figure 9, the original $\mathrm{pH}$ of deionized water being 6.5. Note that if not calcined, after its complete consolidation (21 days) this sample is thermal resistant but not water resistant [8]. All the calcined samples, with the exception of the less than 10 days-old mixtures calcined at $200^{\circ} \mathrm{C}$, are water resistant. The water resistant samples systematically contain crystallized phases, such as cristobalite- or berlinite-type $\mathrm{AlPO}_{4}$, while the non-resistant samples are amorphous. In previous studies $[8,37]$ the water resistance of different geopolymers prepared in phosphoric acid was characterized, showing that this property was not systematic. Some samples indeed were water resistant but not fire 
resistant or, as the present example, fire resistant but not water resistant. In this work, some characteristics of water resistant samples were pointed out. The water resistance was composition and consolidation temperature dependant. Moreover, an NMR study showed that a higher degree of ordering in the networks would favor water resistance [37]. This last point is confirmed in our study, as the ordering of the structure leads to its crystallization.

Moreover, the $\mathrm{pH}$ values measured in immersion water show that the time of reaction does not significantly influence the quantity of acid released in the environment, and the calcination temperature is a more critical parameter. The samples calcined at $200^{\circ} \mathrm{C}$ indeed liberate a larger amount of acidic groups while increasing the calcination temperature leads to a more limited release. This indicates that these species are not strongly bonded to the geopolymeric network, as its formation does not modify the phenomenon. The intensity of the amorphous contribution, centered at approximately $24^{\circ}$, can also be related to this $\mathrm{pH}$ value. As can be seen in Figure 5, this contribution is well visible at $200^{\circ} \mathrm{C}$, intermediate at $500^{\circ} \mathrm{C}$ and it disappears at $1000^{\circ} \mathrm{C}$. The transition from amorphous to crystalline phases in the material thus seems to be the main reason for the limited release of acidic species in the water.

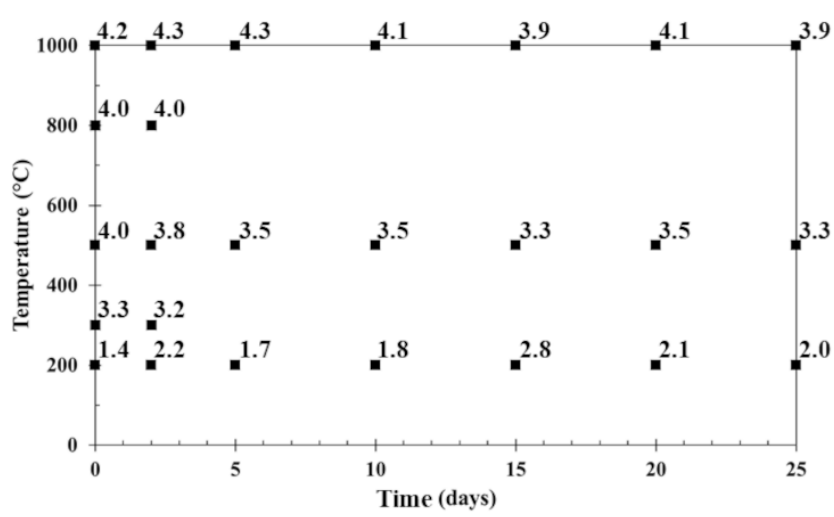

Figure 9: characterization of water resistance through $p H$ values of the water in which specimens are immersed (measurements performed after one day of immersion, starting pH value of reference equal to 6.5). Note that all the calcined samples are water resistant with the exception of the short time / low temperature ones. 


\section{Conclusion}

During their lifetime, acid-based geopolymers can involve various and evolving configurations of phases within their structure, closely depending both on the time and on the temperature of an eventual thermal treatment. This work presents the identification of the networks that form during the polymerization of an acid-based geopolymer by heat-treating the reactive mixture at different ages. By studying the phase transformations induced by time and temperature, it was aimed to understand the steps occurring during the geopolymerization process, and was focused more precisely on the type of networks that are formed at the early stages of the reaction. The FTIR and XRD structural characterizations showed that seven different aluminophosphate-based crystalline phases could appear, associated or not with an amorphous phase. 3-dimensional networks with relatively small rings characterize these compounds; they are probably a good representation of the opening of the structures in the amorphous network. Moreover, three different networks, one based on aluminum in its octahedral configuration, especially visible at the beginning of the geopolymerization, and two based on the tetrahedral configuration of aluminum, were identified in the reactive mixture and later on in the geopolymer. The crystalline phases were identified by both XRD and FTIR, while Si-O-P and $\mathrm{P}=\mathrm{O}$ networks were only observed via FTIR due to their high level of disorder. The water resistance of the calcined samples was tested, and is greatly improved by the thermal treatment even at low temperature. The release of unbounded acidic species in the water is also strongly related to the prior calcination temperature of the samples.

\section{Bibliography}


[1] J. Davidovits, Geopolymer: chemistry and applications, second ed. Saint-Quentin, France: Geopolymer institute; 2008.

[2] A. Gharzouni, E. Joussein, B. Samet, S. Baklouti, S. Rossignol, Effect of the reactivity of alkaline solution and metakaolin on geopolymer formation, J. Non-Cryst. Solids, 2015; 410: 127-134.

[3] A. S. Wagh, Chemically bonded phosphate ceramics, twenty-first century materials with diverse applications ( $2^{\text {nd }} \mathrm{ed}$.), Elsevier, 2016.

[4] H.K. Tchakouté, C.H. Rüscher, Mechanical and microstructural properties of metakaolin-based geopolymer cements from sodium waterglass and phosphoric acid solution as hardeners: a comparative study, Appl. Clay Sci., 2017; 140: 81-87.

[5] H. Celerier, J. Jouin, V. Mathivet, N. Tessier-Doyen, S. Rossignol, Composition and properties of phosphoric acid-based geopolymers, J. Non-Cryst. Solids, 2018; 493: 94-98.

[6] H. Douiri, S. Louati, S. Baklouti, M. Arous, Z. Fakhfakh, Structural, thermal and dielectric properties of phosphoric acid-based geopolymers with different amounts of $\mathrm{H}_{3} \mathrm{PO}_{4}$, Mater. Lett., 2014; 116: 9-12.

[7] L. Le-ping, C. Xue-min, Q. Shu-heng, Y. Jun-li, Z. Lin, Preparation of phosphoric acid-based porous geopolymers, Appl. Clay Sci., 2010; 50: 600-603.

[8] H. Celerier, J. Jouin, N. Tessier-Doyen, S. Rossignol, Influence of various metakaolin raw materials on the water and fire resistance of geopolymers prepared in phosphoric acid, J. Non-Cryst. Solids, 2018; 500: 493-501.

[9] C.N. Bewa, H.K. Tchakouté, D. Fotio, C.H. Rüscher, E. Kamseu, C. Leonelli, Water resistance and thermal behavior of metakaolin-phosphate-based geopolymer cements, Journal of Asian Ceramic Societies, 2018; 6(3): 271-283.

[10] H. Cheng-Yong, L. Yun-Ming, M.M.A.B. Abdullah, K. Hussin, Thermal resistance variations of fly ash geopolymers: foaming responses., Sci. Rep. 2017; 7: 45355.

[11] S. Louati, S. Baklouti, B. Samet, Acid based geopolymerization kinetics: Effect of clay particle size, Appl. Clay Sci., 2016; 132-133: 571-578. 
[12] V. Mathivet, J. Jouin, A. Gharzouni, I. Sobrados, H. Celerier, S. Rossignol, M. Parlier, Acid-based geopolymers: understanding of the structural evolutions during consolidation and after thermal treatments, J. Non-Cryst. Solids, 2019; 512: 90-97.

[13] E.E. Metwalli, R.K. Brow, F.S. Stover, Cation effects on anion distributions in aluminophosphate glasses, J. Am. Ceram. Soc., 2001; 84: 1025-1032.

[14] H.A. Graetsch, High-temperature phase transitions and intermediate incommensurate modulation of the tridymite form of $\mathrm{AlPO}_{4}, \mathrm{Z}$. Kristallogr. 2007; 222: 226233.

[15] L. Le-ping, C. Xue-min, H. Yan, L. Si-dong, G. Si-yu, The phase evolution of phosphoric acid-based geopolymers at elevated temperatures, Mater. Lett., 2012; 66: 10-12.

[16] M.L. Gualtieri, M. Romagnoli, A.F. Gualtieri, Preparation of phosphoric acidbased geopolymer foams using limestone as pore forming agent - Thermal properties by in situ XRPD and Rietveld refinements, J. Eur. Ceram. Soc., 2015; 35: 3167-3178.

[17] D.S. Perera, J.V. Hanna, J. Davis, M.G. Blackford, B.A. Latella, Y. Sasaki, E.R. Vance, Relative strengths of phosphoric acid-reacted and alkali-reacted metakaolin materials, J Mater Sci, 2008; 43: 6562-6566.

[18] R. Dupree, D. Holland, M.G. Mortuza, J.A. Collins, M.W.G. Lockyer, Magic angle spinning NMR of alkali phospho-alumino-silicate glasses, J. Non-Cryst. Solids, 1989; 112: 111-119.

[19] M. Khabbouchi, K. Hosni, M. Mezni, C. Zanelli, M. Doggy, Interaction of metakaolin-phosphoric acid and their structural evolution at high temperature, Appl. Clay. Sci., 2017; 146: 510-516.

[20] M.A. Aramendía, V. Boráu, C. Jiménez, J.M. Marinas, J.R. Ruiz, F.J. Urbano, MAS NMR, DRIFT, and FT-Raman characterization of $\mathrm{SiO}_{2}-\mathrm{AlPO}_{4}-\mathrm{B}_{2} \mathrm{O}_{3}$ ternary catalytic systems, J. Colloid Interface Sci., 1999; 217: 186-193.

[21] G.D. Cody, B. Mysen, G. Sághi-Szabó, J.A. Tossell, Silicate-phosphate interactions in silicate glasses and melts: I. A multinuclear $\left({ }^{27} \mathrm{Al},{ }^{29} \mathrm{Si},{ }^{31} \mathrm{P}\right)$ MAS NMR and ab initio chemical shielding $\left({ }^{31} \mathrm{P}\right)$ study of phosphorous speciation in silicate glasses, Geochim. Cosmochim. Acta, 2001; 65(14): 2395-2411. 
[22] D.J. DiGiovanni, J.B. MacChesney, T.Y. Kometani, Structure and properties of silica containing aluminum and phosphorus near the $\mathrm{AlPO}_{4}$ join, J. Non-Cryst. Solids, 1989; 113: 58-64.

[23] S.G. Kosinski, D.M. Krol, T.M. Duncan, D.C. Douglass, J.B. MacChesney, J.R. Simpson, Raman and NMR spectroscopy of $\mathrm{SiO}_{2}$ glasses co-doped with $\mathrm{Al}_{2} \mathrm{O}_{3}$ and $\mathrm{P}_{2} \mathrm{O}_{5}, \mathrm{~J}$. Non-Cryst. Solids, 1988; 105: 45-52.

[24] A. Gharzouni, I. Sobrados, E. Joussein, S. Baklouti, S. Rossignol, Control of polycondensation reaction generated from different metakaolins and alkaline solutions, J. Ceram. Sci. Technol., 2017; 8: 365-376.

[25] A. Gharzouni, thesis: Contrôle de l'attaque des sources aluminosilicates par la compréhension des solutions alcalines, University of Limoges / University of Sfax, 2016.

[26] O. Masson, PEAKOC profile fitting software v1.0, 2006, available from http://www.esrf.eu/Instrumentation/software/data-analysis/OurSoftware/PEAKOC.

[27] H.K. Ting, S. . Page, G. Poologasundarampillai, S. Chen, B. Yu, J.V. Hanna, J.R. Jones, Phosphate content affects structure and bioactivity of sol-gel silicate bioactive glasses, Int. J. Appl. Glass. Sci., 2017; 8: 372-382.

[28] L.S. Burrell, C.T. Johnston, D. Schulze, J. Klein, J.L. White, S.L. Hem, Aluminium phosphate adjuvants prepared by precipitation at constant $\mathrm{pH}$. Part I: composition and structure, Vaccine, 2001; 19: 275-281.

[29] S. Gypser, F. Hirsch, A.M. Schleicher, D. Freese, Impact of crystalline and amorphous iron- and aluminum hydroxides on mechanisms of phosphate adsorption and desorption, J . Envir. Sci., 2018; 70: 175-189.

[30] HK Ting, S.J. Page, G. Poologasundarampillai, S. Chen, B. Yu, J.V. Hanna, J.R. Jones, Phosphate content affects structure and bioactivity of sol-gel silicate bioactive glasses, Int J Appl Glass Sci 2017; 8(4): 372-386.

[31] D. Koloušek, J. Brus, M. Urbanova, J. Andertova, V. Hulinsky, J. Vorel, Preparation, structure and hydrothermal stability of alternative (sodium silicate-free) geopolymers, J. Non-Cryst. Solids, 2007; 42: 9267-9275.

[32] N.V. Chukanov, A.D. Chervonnyi, Infrared spectroscopy of minerals and related compounds, Springer Mineralogy, Springer International Publishing Switzerland, 2016, 1109p. 
[33] R.L. Frost, R. Scholz, F.M. Belotti, A. López, F.L. Theiss, A vibrational spectroscopic study of the phosphate mineral vantasselite $\mathrm{Al}_{4}\left(\mathrm{PO}_{4}\right)_{3}(\mathrm{OH})_{3} \cdot 9 \mathrm{H}_{2} \mathrm{O}$, Spectrochimica Acta Part A: Molecular and Biomolecular Spectroscopy, 2015; 147: 185-192.

[34] M. Rokita, M. Handke, W. Mozgawa, The $\mathrm{AIPO}_{4}$ polymorphs structure in the light of Raman and IR spectroscopy studies, Journal of Molecular Structure, 2000; 555: 351-356.

[35] M. Rokita, M Handke, W. Mozgawa, Spectroscopic studies of the amorphous $\mathrm{SiO}_{2}-\mathrm{AlPO}_{4}$ materials, Journal of molecular structure, 1999; 511-512: 277-280.

[36] M. Kamal, I.K. Battisha, M.A. Salem, A.M.S. El Nahrawy, Structural and thermal properties of monolithic silica-phosphate $\left(\mathrm{SiO}_{2}-\mathrm{P}_{2} \mathrm{O}_{5}\right)$ gel glasses prepared by sol-gel technique, J. Sol. Gel Sci. Technol., 2011; 58: 507-521.

[37] H. Celerier, J. Jouin, A. Gharzouni, V. Mathivet, I. Sobrados, N. Tessier-Doyen, S. Rossignol, Relation between working properties and structural properties from ${ }^{27} \mathrm{Al},{ }^{29} \mathrm{Si}$ and ${ }^{31} \mathrm{P}$ NMR and XRD of acid-based geopolymers from 25 to $1000^{\circ} \mathrm{C}$, Materials Chemistry and Physics, 2019; 228: 293-302.

[38] R. Brill, A.P. de Bretteville, On the chemical bond type in $\mathrm{AlPO}_{4}$, Acta Crystallographica, 1955; 8: 567-570.

[39] H. Graetsch, Two Forms of aluminium phosphate tridymite from X-ray powder data, Acta Crystallographica, 2000; C56: 401-403.

[40] S.N. Achary, O.D. Jayakumar, A.K. Tyagi, S.K. Kulshreshtha, Preparation, phase transition and thermal expansion studies on low-cristobalite type $\mathrm{Al}_{1-\mathrm{x}} \mathrm{Ga}_{\mathrm{x}} \mathrm{PO}_{4}(\mathrm{x}=0.0,0.20$, 0.50, 0.80 and 1.00), Journal of Solid State Chemistry, 2003; 176: 37-46.

[41] J.M. Bennet, W.J. Dytrych, J.J. Pluth, J.W. Richardson Jr, J.V. Smith, Structural features of aluminophosphate materials with $\mathrm{Al} / \mathrm{P}=1$, Zeolites, 1986; 6: 349-359.

[42] J.W. Richardson jr., J.V. Smith, J.P. Pluth, AlPO 4 -25: Framework topology, topotactic transformation from $\mathrm{AlPO}_{4}-21$, and high-low displacive transition, Journal of Physical Chemistry, 1990; 94: 3365-3367.

[43] E.B. Keller, W.M. Meier, R.M. Kirchner, Synthesis, structures of $\mathrm{AlPO}_{4}-\mathrm{C}$ and $\mathrm{AlPO}_{4}-\mathrm{D}$ and their topotactic transformation, Solid State Ionics, 1990; 43: 93-102. 
[44] F. d'Yvoire, Etude des phosphates d'aluminium et de fer trivalent. I. L'orthophosphate neutre d'aluminum, Bull. Soc. Chem. France, 1961; 12: 1762-1776.

[45] D. Fratzky, M. Schneider, M. Meisel, Crystal structure of aluminium cyclononaphosphate $\mathrm{Al}_{3} \mathrm{P}_{9} \mathrm{O}_{28}$, Zeitschrift fuer Kristallographie - New Crystal Structures, 2000; 215: 341-342.

[46] V.A. Lyutsko, A.S. Lyakhov, G.K. Tuchkovskii, K.K. Palkina, Investigation of crystal structure of aluminium dihydridophosphate $\mathrm{AlH}_{2} \mathrm{P}_{3} \mathrm{O}_{10}-\mathrm{II}$, Zhurnal Neorganicheskoi Khimii, 1991; 36: 1165-1169.

[47] H. Kominami, K. Matsuo, Y. Kera, Crystallization and transformation of aluminum orthophosphates in organic solvent containing a small amount of water, $\mathrm{J}$ Amer. Ceram.Soc, 1996; 79(9): 2506-2508.

[48] T. Rey, Ultrarotabsorption von $\mathrm{AlPO}_{4}$ und $\mathrm{SiO}_{2}$ in Abhängigkeit von Fehlordnung und Temperatur, Z. Kristallogr, 1966; 123: 263-314.

[49] C. Baerlocher, L.B. McCusker, D.H. Olson, Atlas of Zeolite Framework Types, Sixth Revised Edition, Elsevier; 2007: 404p. 